Marine Research in Indonesia No. 18, 1977: 1 -11.

\title{
THE MANAGEMENT OF MANGROVES IN AN URBAN SITUATION
}

\author{
by \\ P.A. HUTCHING ${ }^{1)}$ and H.F. RECHER ${ }^{1)}$
}

\begin{abstract}
Sydney is an affluent city of nearly three million people surrounding three well developed estuaries and a shallow protected bay. These areas all originally had extensive wetlands of salt marsh, mangroves and sea-grass flats. The areas are now being rapidly reclaimed or destroyed by port development, marinas, canal estate development, playing fields, garbage tips or damaged by industry. They are also economically important fishing and oyster farming areas and the water masses are heavily used for recreation. In this paper we have selected three areas of wetlands in this region, threatened by different types of development and we discuss their ecology and their traditional biological attributes and the unique attributes that such areas have in an urban affluent society. These are their educational and recreational values to the community. We describe the planning of an education field centre adjacent to an urbanized wetland area and construction of boardwalks through the mangroves.
\end{abstract}

\section{INTRODUCTION}

Though it is recognised that mangrove, sea-grass and salt marsh communities contribute significantly to the productivity of estuaries, their destruction continues at an accelerating rate throughout the world. Australia is no exception. The growth of Australia's economy and population over the past thirty years has been accompanied by extensive destruction of estuarine environments. The impact has been particularly great on estuaries near the major cities of the east coast: Townsville, Brisbane, Newcastle, Sydney and Melbourne, where large areas have been reclaimed or dredged for industry and port development, used for garbage disposal or filled to provide recreation areas. An increasing demand for residential water frontage has accelerated the rate of reclamation of shallow water habitats.

Until recently the destruction of estuaries was accepted by Australians as the price of progress. Now however, recognition of the biological importance of shallow water communities and concern for environmental quality has led to widespread opposition to the destruction of estuarine environments. The opposition has been strongest in Sydney, Brisbane and Melbourne where coalitions of resident action groups and biologists have prevented or substantially modified a number of proposed developments. In many cases they have been supported by local government and the trade union movement (HARDMAN \& MANDING 1974).

1). The Australian Museum Sydney, N.S.W., AUSTRALIA. 
In the present social climate of Australia, the conservation of mangrove and sea-grass environments in the large cities acquires particular importance. Not only are they productive habitats, but they provide unique opportunities for recreation, education and scientific research. During the past five years we have participated actively as biologists and environmental advocates for the conservation of mangroves in Sydney and its satellite growth centres (HATTERSLEY et al. 1973, HutCHings \& RECHER 1974). Our experience provides a framework on which, the conservation of estuaries and mangroves may be achieved in other urban centres. In this paper we discuss the conservation of mangroves and associated plant communities in Sydney and suggest ways in which these parts of the estuary can retain their important biological functions and contribute directly to the recreational, educational and scientific opportunities of the urban ecosystem. Finally we compare the roles of mangroves in a country like Australia to those in developing countries.

\section{THE ENVIRONMENT}

Visitors tend to associate Sydney ( $\left.33^{\circ} \mathrm{S}, 151^{\circ} \mathrm{E}\right)$ with Port Jackson and Botany Bay, but the city extends along the coast forming a conurbation with Newcastle to the north and Wollongsong to the south. Sydney and its suburbs alone have a population of three million (more than twenty per cent of Australia's total population) extending along sixty $\mathrm{km}$ of coast and embracing four major estuaries: Port Jackson, Botany Bay, Port Hacking and the Hawkesbury River - Broken Bay system, which includes Pittwater and Brisbane Water (Fig. 1). Originally the shores of these estuaries were fringed with extensive stands of mangroves, salt marsh, fresh-water wetlands and sea-grass flats. Though these estuaries have been substantially modified and large areas reclaimed (GoODRICK 1970), they remain largely unpolluted and contribute significantly to the fisheries resources of New South Wales. POLLARD (1976) estimated that the value of estuarine fisheries in New South Wales for 1970 was A\$ 8 million for oysters, prawns and fish taken directly from the estuaries and A 4 million for fish and prawns taken at sea but dependent upon the estuaries for their production. The value in 1976 would be much higher and represents seventy per cent of New South Wales' entire fisheries resources. Nearly forty per cent of New South Wales' oysters and a substantial part of its fish and prawns are produced in the estuaries bounded by Sydney and its suburbs (Table I). 
THE MANAGEMENT OF MANGROVES

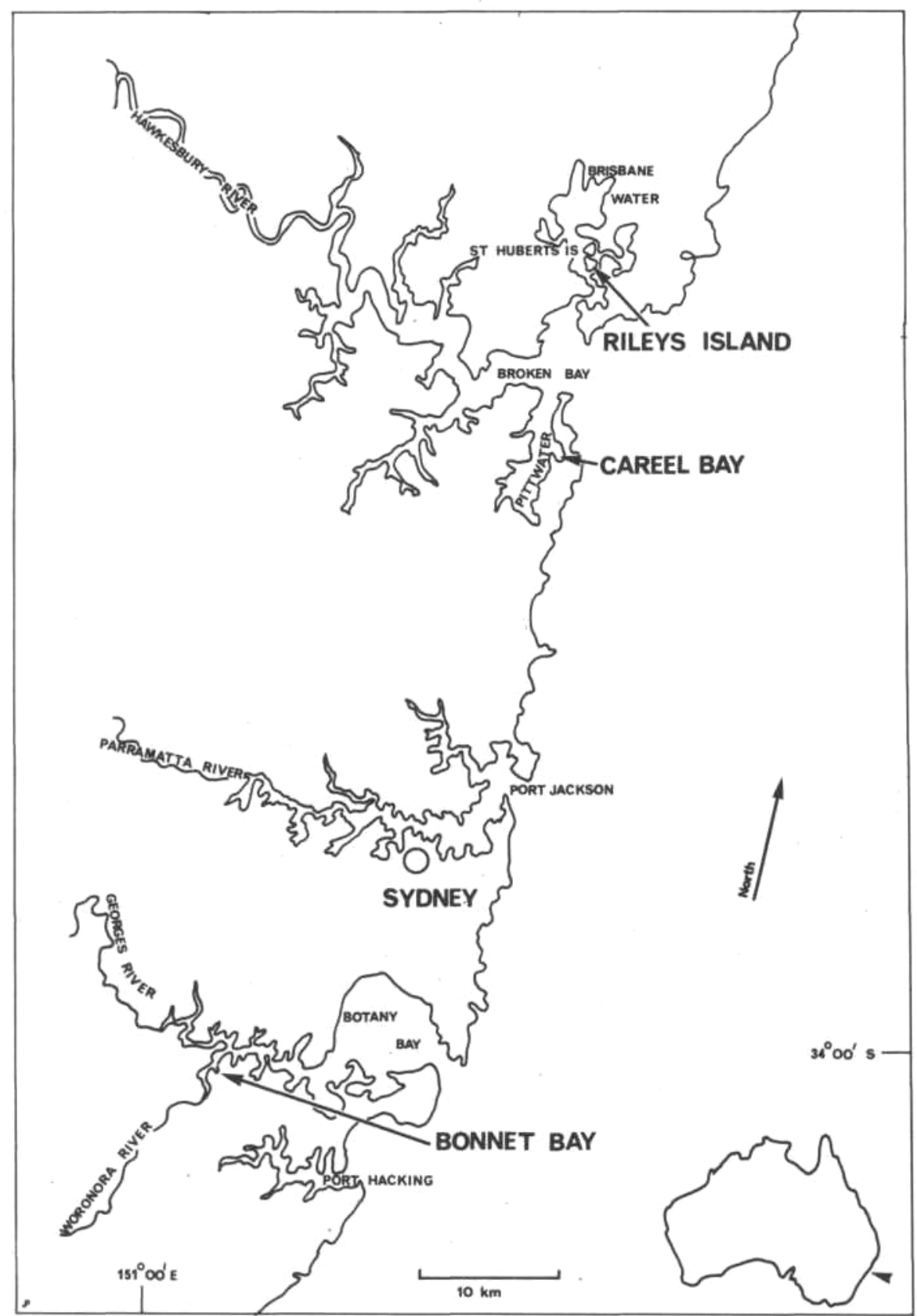

Figure 1. The location of the three study areas: Rileys Island. Careel Bay and Bonnet Bay. 
P.A. HUTCHINGS \& H.F. RECHER

Table I. Oyster production in bags of Sydney Estuaries

\begin{tabular}{|c|c|c|c|c|c|c|c|c|}
\hline & $\begin{array}{l}1965 \\
1966\end{array}$ & $\begin{array}{l}1966 \\
1967\end{array}$ & $\begin{array}{l}1967 \\
1968\end{array}$ & $\begin{array}{l}1968 \\
1969\end{array}$ & $\begin{array}{l}1969 \\
1970\end{array}$ & $\begin{array}{l}1970 \\
1971\end{array}$ & $\begin{array}{l}1971 \\
1972\end{array}$ & $\begin{array}{l}1972 \\
1973\end{array}$ \\
\hline Georges River & 30,139 & 26,027 & 27,408 & 27,125 & 33,827 & 34,999 & 41,068 & 33,475 \\
\hline $\begin{array}{l}\text { Hawkesbury River } \\
\text { Brisbane Water } \\
\text { Port Hacking }\end{array}$ & 6,755 & 10,521 & 11,092 & $\begin{array}{r}14,143 \\
510 \\
10\end{array}$ & $\begin{array}{r}21,232 \\
760\end{array}$ & $\begin{array}{r}19,250 \\
652\end{array}$ & $\begin{array}{r}15,085 \\
1,084 \\
110\end{array}$ & $\begin{array}{c}13,957 \\
1,469\end{array}$ \\
\hline $\begin{array}{l}\text { Total No. Bags } \\
\text { Total N.S.W. State } \\
\text { Production } \\
\text { Percentage of State's } \\
\text { Production from Sydney } \\
\text { Estuaries }\end{array}$ & $\begin{array}{c}36,894 \\
\text { n.a. }\end{array}$ & $\begin{array}{c}36,548 \\
\text { n.a. }\end{array}$ & $\begin{array}{c}38,500 \\
\text { n.a. }\end{array}$ & $\begin{array}{c}41,788 \\
\text { n.a. }\end{array}$ & $\begin{array}{l}55,819 \\
154,310 \\
36.17 \%\end{array}$ & $\begin{array}{l}54,901 \\
132,842 \\
41.32 \%\end{array}$ & $\begin{array}{l}57,347 \\
140,875 \\
40.70 \%\end{array}$ & $\begin{array}{c}\text { 48,901 } \\
\text { n.a. }\end{array}$ \\
\hline
\end{tabular}

n.a. = not available Source:

N.S.W. State Fisheries Annual Reports

\section{STUDY AREAS}

Three of our study areas have been selected to indicate some of the pressures being applied to wetlands in the Sydney region: (1) Careel Bay (2) Riley's and St. Hubert's Islands and (3) Bonnets Bay (Fig. 1). Other important wetland areas are also threatened by development in the Sydney region, the most significant of these is the major estuary of Botany Bay. Substantial development of the Bay's northern shores is proceeding to provide land for heavy industry and port development. The removal of sand from the Bay and the changed patterns of currents resulting from extensive reclamation, is leading to errosion of beaches, sea-grass beds and mangrove swamps along the southern and eastern shores of the Bay. The impact of development of Botany Bay has been the subject of very considerable public concern in Sydney and the issue has been discussed at length by ANDERSON (1974), LARKUM (1976) and LAWLER (1971).

1. Careel Bay, a sheltered, almost totally marine bay on the south eastern shores of Pittwater, $32 \mathrm{~km}$ north of Sydney, probably resembles the shallow water communities which were present in the lower parts of Sydney's estuaries prior to settlement by Europeans, but we lack detailed knowledge of wetland areas prior to 1950 (CLARKe \& HANNON 1967, 1969, 1970, 1971). Careel Bay has a well developed salt marsh with a 
terrestrial border of Casuarina glauca, flanked to the Bay by mangrove and sea-grass communities. Two species of mangroves are present, Aegiceras corniculatum and Avicennia marina, the latter being dominant and reaching a maximum height of eight metres. The sea-grass flats are composed of two distinct zones, the upper zone of Zostera capricorni and Heterozostera tasmanica, exposed at low tide, and a lower zone of Posidonia australis, from below mean low water to a depth of six metres. The distribution and abundance of the fauna with the associated plant communities has been described by HutCHINGS \& RECHER (1974). Part of the salt marsh and mangrove area has already been filled in by a municipal garbage tip and the resulting reclaimed land converted to playing fields (Plate 1).

A proposal to build a marina in this Bay was presented to the local government authority, Warringah Shire Council, in 1971. This development necessitated the complete destruction of the sea-grass flats by dredging to provide deep water moorings and the dumping of dredge ,spoils onto the mangroves and salt marsh. The area reclaimed would have provided land for the marina compelx and car parking. The Avalon Preservation Trust, a local resident action group, objected to the proposal and requested the council to fund an environmental survey of the area and asses the impact of the marina development on, the surrounding area. The initial survey (HATTERSLEY et al. 1973) indicated that this wetland area was rich in species and appeared to be richer than other comparable areas in the Sydney area. The reasons for its richness are not fully understood, even though Careel Bay is surrounded by residential development it is relatively undisturbed. Pitt water, into which Careel Bay opens, is also residential on its southern shores but with substantial areas on its northern shores reserved as Kuringai Chase National Park. Careel Bay has a salinity approaching that of sea water as no major river drains into Careel Bay or Pittwater, with good tidal flushing occurring. Water quality and clarity are high, allowing dense sea-grass beds to flourish. All these factors probably contribute to the richness of the fauna of Careel Bay and DAY (1976) has found similar factors operating in South African estuaries.

The council accepted the report by HATTERSLEY et al. (1973) and commissioned another report to be prepared in conjunction with town planners, biologists and engineers on ways in which the area could be used, yet retain its natural value to the community (FOSTER et al. 1974). The recommendations of this second report are discussed at the end of the paper.

2. Riley's and St. Hubert's Islands are situated in Brisbane Water in the Gosford-Wyong area, a rapidly growing satellite of Sydney. St. Hubert's Island, originally a low mangrove-fringed island, was developed in 
the late 1960's as a residential canal estate (Plate 1). (For a recent review of the impact of such development see WESTMAN 1975). The island was developed by dredging deep water channels and using the dredged sand to raise the level of the land for housing. Each home site, therefore, has a deep water frontage. Homesites on St. Hubert's are among the most expensive in the Gosford region with an eight hundred square metre block selling for about A \$20,000. The same developer, Hooker Rex Pty Ltd, also wishes to develop the adjacent Riley's Island, which is fringed by mangroves and has an extensive salt marsh dominated by samphire, Salicornia, with scattered mangroves Aegiceras corniculatum. The higher parts of Riley's Island have a well developed forest of she oak, Casuarina sp., paperbark, Melaleuca sp., and Eucalyptus. A canal estate similar to the one on St. Hubert's has been proposed for Riley's Island. Local residents who wish to retain Brisbane Water as a recreation and fishing area have appealed to the local council to prevent the development of Riley's Island. It is argued that Riley's Island should remain as open space and that further residential development should be restricted to environments which are ecologically less sensitive. As open space, Riley's Island could be available for limited recreation, but most importantly it could continue to contribute to the marine productivity of Brisbane Water.

It is ironical that people purchasing canal estate blocks to enjoy the recreation and fishing amenities of Brisbane Water are in fact destroying the shallow water plant communities which support the very fisheries they wish to enjoy.

To date development of Riley's Island has been blocked by a "Green Ban" ( HARIMAN \& MANNING 1974) imposed by the Central Coast Trade Labour Council. The Green Ban prevents any union member working on the Island, and is based on the argument that the worker must be responsible for the result of his labour. In the case of Riley's Island, the Labour Movement feels that the Island has greater environmental, social and economic value in its present state than if it were developed for housing.

3. Bonnets Bay, another area in Sydney where mangroves are threatened by residential development, this time indirectly. Bonnets Bay, on the Woronora River which opens into the Georges River and then into Botany Bay (Fig. 1), is a shallow muddy bay used as a commercial fattening area for oysters, Saccostraa cucullata. A small creek flows into the Bay. Surrounding the margins of Bonnets Bay are narrower stands of mangroves, Aegiceras corniculatum and Avicennia marina. At the terrestrial border there is a narrow band of Casuarina and Juncus and then steep sandstone cliffs. In the centre of the Bay isolated patches of Zostera are present. Bonnets 
Bay is one of the few surviving examples in Sydney of mangroves in a brackish environment. Elsewhere on the upper reaches of the Georges and Parramatta Rivers mangroves have been largely reclaimed for housing and industry. When the original stands of mangroves are plotted for the southern shores of Woronora River and compared with the stands remaining in 1976, it is seen that Bonnets Bay and Mangrove Island represent the only two remaining stands (Fig. 2). Woolaware Bay, the site of the classic work by HANNON \& CLARKE $(1967,1969,1970,1971)$ has already been reclaimed for residential purposes.

At the top of the steep sandstone cliffs surrounding Bonnets Bay, residential development has occurred. A proposal is currently being considered to build a road halfway down the cliff thus opening up and additional twenty building sites. These sites would have no water view, only mangroves, and it is feared that the mangroves would be cleared eventually to provide water frontages and views, as happened on St. Hubert's Island. The construction of the road and subsequent development of houses will, in a geologist's opinion cause major subsidence and instability (BRANAGAN et al 1976). The area is not sewered and already after heavy rain the creek and fresh water run off is contaminated by domestic wastes. Suspended organic solids are very high at these times, and the biological oxygen demand, coupled with the high nutrient levels, creates a heavy pollutant loading in the Bay, which may already affect oyster mariculture and recreation. Although the destruction of this small stand of mangroves may have little effect on the productivity of the river as a whole, Bonnets Bay has an important scientific value as an upstream mangrove area. 


\section{P.A. Hutchings \& H.F. RecheR}

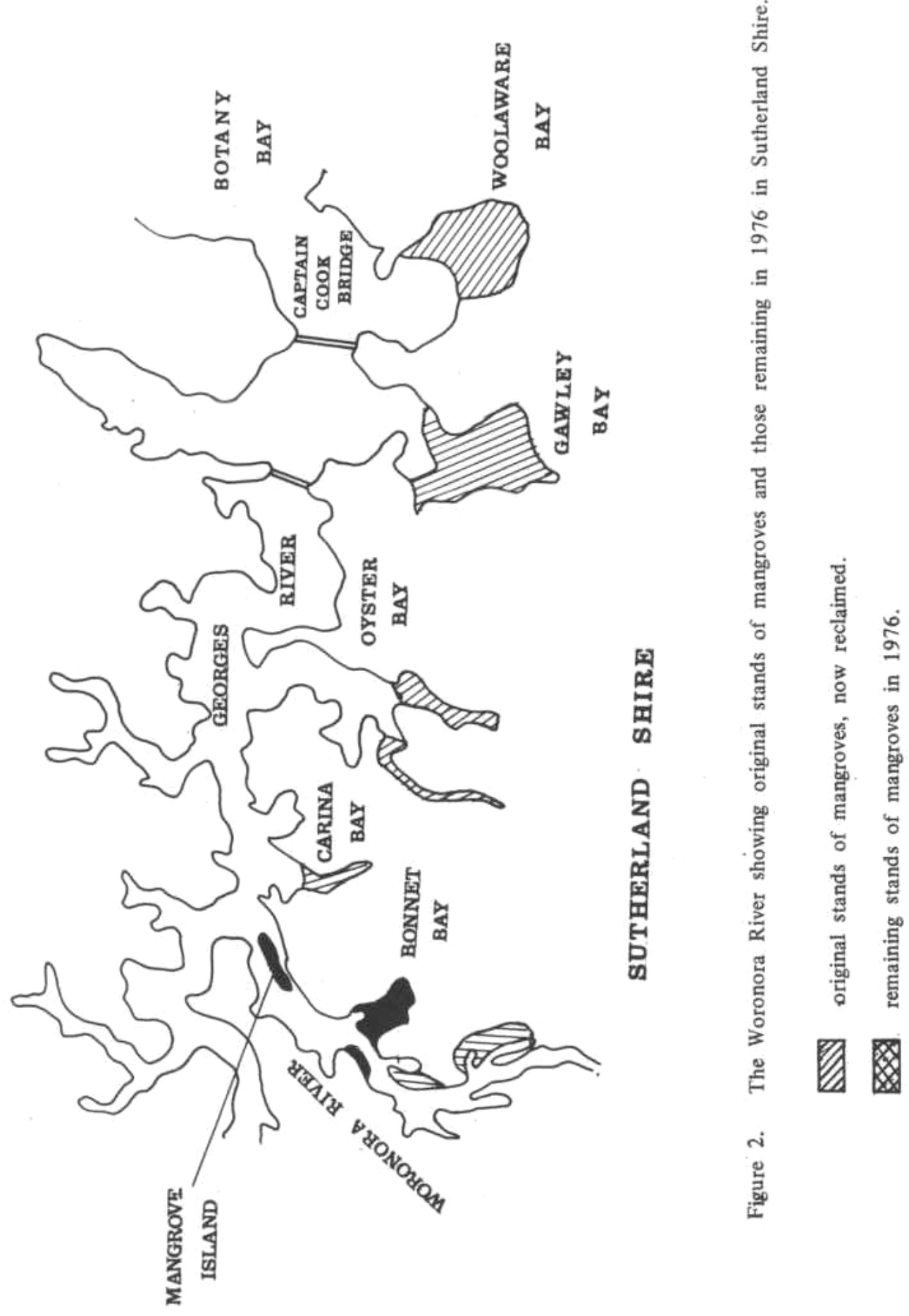


Australia and the U.S.A. may be in a unique position in being able to retain wetland areas for recreation, educational and scientific uses, which are directly compatible with the biological value of the wetlands and estuaries to fisheries. For these two countries have no used to harvest wood from the wetlands, for charcoal, building needs etc., or to clear mangroves to provide land for cultivation or fish ponds. In less developed countries such as Indonesia and Malaysia there are considerable economic uses for wetlands, i.e. wood, charcoal, land and fish farms. So that effectively all countries are destroying their wetlands but for very different reasons. In Australia and the U.S.A. for high cost residential land, garbage tips, playing fields and in less well developed areas for tangible economic reasons. But in both cases estuaries and fishing industries are being severely affected, but to what extent is at present unknown, and yet many undeveloped countries are heavily dependent upon their fisheries as a source of protein.

\section{REFERENCES}

ANDERSON, D.J. 1974. A Handbook of the Botany Bay region - Some preliminary background papers - Botany Bay Project Committee Report. Published O'Grady and Sons. Mar-rackville, Sydney.

Branagan, D.F., PA Hutchings, H. Recher, D. Black and P. Collis, 1976. Report on the environmental impact of a proposed residential development at Bonnet Bay. Unpublished report presented to Sutherland Shire Council, Sydney.

CLARKE, L. and N. HANNON 1967. The Mangrove swamp and salt marsh communities of the Sydney District. I. Vegetation, soils and climate. J. Ecol. $55: 753 \quad 772$.

CLARKE, L. and N. HANNON 1969. The Mangrove swamp and salt marsh communities of the Sydney District. II. The holocoenotic complex with particular reference to physiography. Ecol 57: $213-234$.

CLARKE, L. and N. HANNON 1970. The Mangrove swamp and salt marsh communities of the Sydney District. II. Plant growth in relation to salinity and water logging. J. Ecol. $58: 351-370$.

CLARKE, L. and N. HANNON 1971. The Mangrove swamp and salt marsh communities of the Sydney District. IV. The significance of species interaction. J. Ecol. 59 : 535 - 554.

DAY, J.H. 1967. The biology of Knysna estuary, South Africa. In : "Estuaries", American Assoc. Advan. Sci. Publ. $83: 397407$.

Foster, D.N.,P.A. Hutchings, Z. Nittim, R. Nittim and H.F. Recher 1974. Careel Bay, Pittwater N.S.N. development proposal for the recreational and cultural use of the bay. University N.S.W. Research Laboratory, Tech. Rep. No. 74/21, 13 pp.

GOODRICK, G.N. 1970. A Survey of the Wetlands of Coastal N.S.W. C.S.I.R.O. Division of Wildlife Res. Technical Memo No. 5 Sept.

Hardman, M. and P. MANNING 1974. Green Bans. An Australian Conservation Foundation Publication Melbourne, $127 \mathrm{pp}$.

Hattersley, RT.; P.A, Hutchings and H.F. Recher 1973. Careel Bay, Pittwater,N.S.W. Development Proposals. Environmental Studies, University N.S.W. Water Research Laboratory, Tech. Rep. No. 73/6, 35pp. 


\section{P.A. HUTCHINGS \& H.F. RECHER}

HUTCHINGS, P.A and H.F. RECHER 1974. The Fauna of Careel Bay with comments on the ecology of mangrove and sea-grass communities. Aust. Zool. 18(2) : 99 - 128.

LARKum, A.W. 1976. Ecology of Botany Bay. I. Growth of Posidonia australis (BROWN) Hook f. in Botany Bay and other bays of the Sydney Basin. Aust. J. Mar. Freshwater Res. 27(1) : 117 - 135.

Lawler, C.J. 1971. Lament for Botany Bay. Aust. Nat. Hist. 17(3) : 78 - 82.

POLLARD, D. 1976. Estuaries must be protected. Aust. Fisheries 36(6) : 6 - 10.

WESTMAN, W.E. 1975. Ecology of Canal Estates. Search 6(11 - 12) : 491 - 498. 


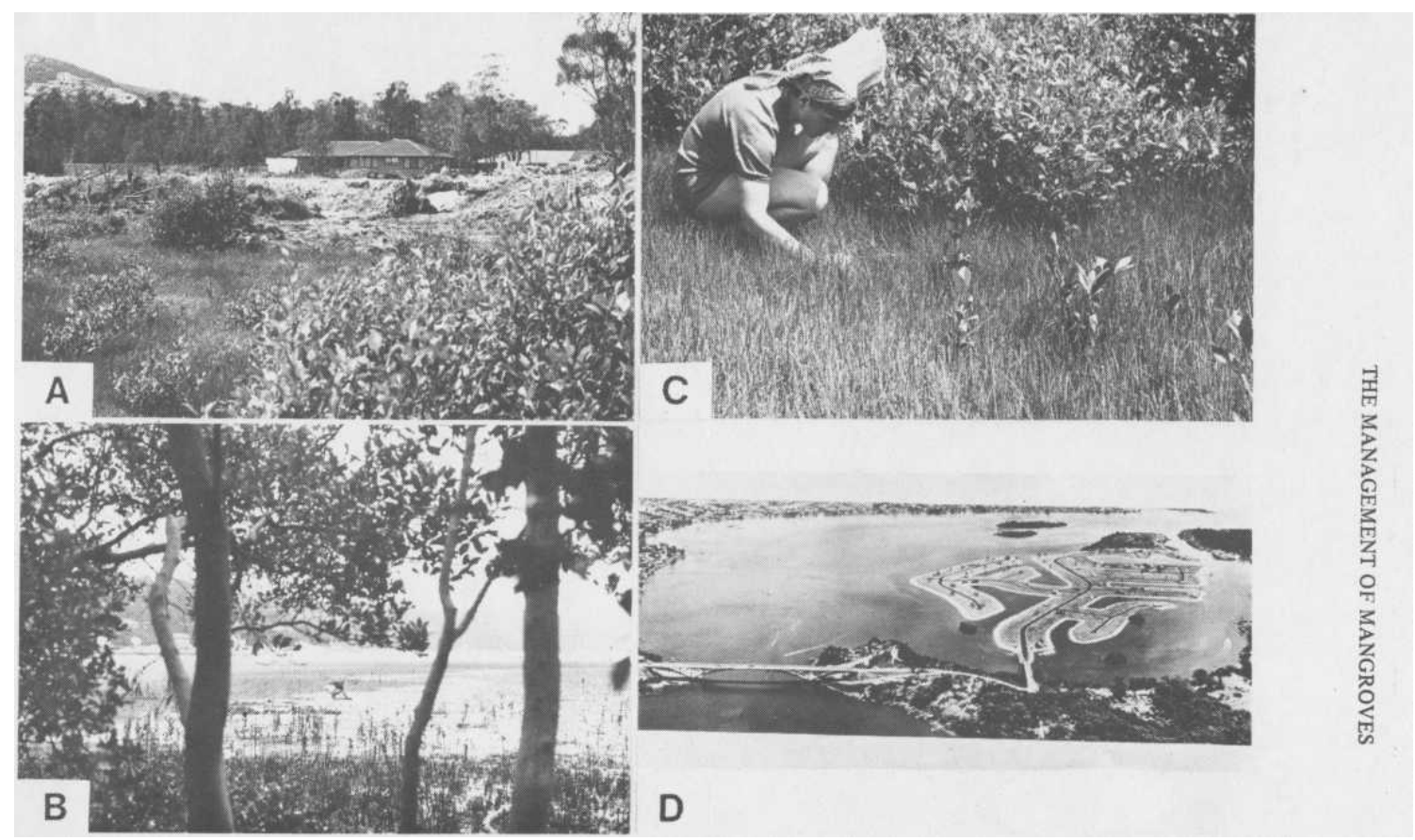

Plate I. A. Residential encroachment on salt marsh at Careel Bay. (Photo H. Recher). B. Margins of undisturbed salt marsh with young Avicennia and Salicornia at Careel Bay in area proposed to be reclaimed for playing fields.

(Photo H. Recher). C. Zosterq sea grass beds at low tide bordering Avicennia forests at Careel Bay, in area proposed to be reclaimed for marina development (Photo D. Lunney). D. Aerial view of canal estate at St. Hubert's Island with presently undeveloped Riley's Island to the far right, soon after reclamation was completed (Photo H. Recher). 